\title{
Marginalizacja ugrupowań ekologicznych na scenach politycznych państw Europy Środkowo-Wschodniej w okresie transformacji ustrojowej
}

\section{Wprowadzenie}

Partie ekologiczne (enwironmentalistyczne) ${ }^{1}$ odgrywaja w dzisiejszej $\mathrm{w}$ europejskich systemach partyjnych jest $\mathrm{w}$ dużej mierze związana

1 Na potrzeby niniejszego artykułu przyjęto, że synonimem wyrażenia ,partie ekologiczne" jest coraz częściej pojawiające się w literaturze anglosaskiej wyrażenie „environmental parties” (partie enwironmentalistyczne). Por. M. Perottino, The Green Party: an undeserved success?, w: Social Movements and Public Action Lessons from Environmental Issues, red. P. Marty, S. Devaux, Prague 2009, s. 55; B. M. Meguid, Party Competition between Unequals Strategies and Electoral Fortunes in Western Europe, New York 2008, s. 2. Samo pojęcie partii ekologicznych jest obecnie różnorako definiowane. Jako swoiste ruchy polityczne nowego typu mają się one odróżniać od innych ugrupowań politycznych trzema podstawowymi cechami (typologia prof. Herberta Kitschelta):

1) słabe mechanizmy wiążące działaczy partii, odzwierciedlone zarówno w ograniczonych poziomach członkostwa w partii (zmiana statusu z członka partii na aktywistę);

2) odrzucenie tradycyjnej biurokratycznej organizacji partii na rzecz zdecentralizowanego organizmu, który ma na celu zmobilizować działaczy i poziomo skoordynowana mobilizacja działaczy;

3) nacisk na zbiorowe podejmowanie decyzji.

Zob. szerzej: J. Burchell, The Evolution of Green Politics. Development and Change within European Green Parties, London 2002, s. 17.

$\mathrm{Z}$ kolei prof. Andrzej Antoszewski wskazuje na funkcjonujący szczególnie w zachodnioeuropejskiej nauce pogląd o partiach ekologicznych jako o ugrupowaniach niedających wpisać się w oś prawica-lewica, przez część badaczy uważanych nawet za swego rodzaju ,antypartię”. Por. A. Antoszewski, Partie i systemy partyjne państw Unii Europejskiej na przełomie wieków, Toruń 2009, s. 194.

${ }^{2}$ Za potwierdzenie tej tezy niech świadczy chociażby obsadzenie urzędu premiera niemieckiego landu (Baden-Württemberg) po raz pierwszy w historii przez 
z poziomem rozwoju gospodarczo-społecznego. Im bardziej system gospodarczo-społeczny państwa jest rozwinięty, tym partia ekologiczna odgrywa większą rolę w systemie (np. wchodzi w skład koalicji rządzącej) ${ }^{3}$. Mimo dużego zainteresowania tematyką ochrony środowiska ze strony instytucji europejskich (w szczególności Unii Europejskiej), w których skład wchodzą przecież również urzędnicy pochodzący z tzw. nowych państw członkowskich, programy polityczne partii ekologicznych są przez społeczeństwa Europy Środkowo-Wschodniej odrzucane, a same ugrupowania są jedynie przejściowym składnikiem systemów partyjnych tych państw. Autor, odnosząc się do koncepcji Allana Sikka i Rune'a Holmgaarda Andersena powstałej w odniesieniu do ewolucji estońskiego ruchu politycznego po 1989 roku, dokonuje próby jej przeniesienia na systemy partyjne innych państw omawianego regionu.

Jeżeli do grona państw Europy Środkowo-Wschodniej zaliczylibyśmy 17 podmiotów (Albania, Bośnia i Hercegowina, Bułgaria, Chorwacja, Czarnogóra, Czechy, Estonia, Litwa, Łotwa, Macedonia, Mołdawia, Polska, Rumunia, Serbia, Słowacja, Słowenia, Węgry) ${ }^{4}$, to zauważymy, że, w stosunku do scen politycznych państw zachodnioeuropejskich, tyl-

polityka wywodzącego się z ruchu ekologicznego (Winfried Kretschmann). Zob. szerzej: K. Kęciek, Zielony cud w Niemczech, http://www.przeglad-tygodnik.pl/pl/ artykul/zielony-cud-niemczech, dostęp 30.09.2011 r.

Nie należy również zapominać o bardzo dużym wpływie ruchów ekologicznych na decyzję kanclerz Angeli Merkel o zamknięciu najstarszych niemieckich elektrowni atomowych.

${ }^{3}$ Przykładem może być chociażby okres od 1998 do 2005 r., kiedy to niemiecki Związek 90/Zieloni tworzył koalicję rządową z Socjaldemokratyczną Partią Niemiec (SPD). Funkcjonowanie niemieckiego ugrupowania enwironmentalistycznego (Zieloni - Die Grünen) na scenie politycznej RFN jest przedmiotem analiz wielu autorów. Warto wspomnieć chociażby o dwóch pracach: S. Rudnik, Partia Zielonych w systemie politycznym RFN, Wyższa Szkoła Pedagogiczna w Słupsku, Słupsk 1994; W. Miziniak, Zieloni w Republice Federalnej Niemiec, Instytut Zachodni, Poznań 1990.

W przeciwieństwie do zakresu badań nad środkowoeuropejskimi ugrupowaniami ekologicznymi, o partiach enwiromentalistycznych funkcjonujących na scenach politycznych Europy Zachodniej powstaje bardzo wiele opracowań. Jednym z ostatnich takich opracowań jest praca zbiorowa Green Parties in Transition The End of Grass-roots Democracy?, pod redakcją trzech autorów: E. Gene Frankland, Paul Lucardie i Benoît Rihoux wydana w 2008 roku.

${ }^{4}$ Autor na potrzeby niniejszego artykułu przyjmuje, że do państw Europy Środkowo-Wschodniej nie zalicza się Ukrainy i Białorusi jako państw wschodnioeuropejskich. 
ko w niewielu z nich, partie ekologiczne osiagają poparcie na tyle wysokie w wyborach, ażeby mogły partycypować w podziale mandatów parlamentarnych. Przedmiotem artykułu, poza ugrupowaniami enwironmentalistycznymi państw Grupy Wyszehradzkiej i państw bałtyckich, są też partie ekologiczne w Albanii, Bułgarii, Macedonii, Rumunii i Słowenii ${ }^{5}$. Polityczne ruchy ekologiczne w pozostałych państwach bałkańskich (w Bośni i Hercegowinie, Chorwacji, Czarnogórze oraz Serbii) nie odgrywają znaczącej roli nawet pośród partii pozaparlamentarnych lub ugrupowania takie nawet nie występują ${ }^{6}$.

\section{Koncepcja Allana Sikka i Rune’a Holmgaarda Andersena}

Allan Sikk i Rune Holmgaard Andersen w swoim opracowaniu Without a Tinge of Red: The Fall and Rise of Estonian Greens ${ }^{7}$ zwracaja uwagę, że w rozwoju estońskich partii ekologicznych wyróżnić można trzy fazy:

- faza pierwsza (1987-1992) - okres wzrostu znaczenia ruchu ekologicznego i jego przekształcenia się w Partię Zielonych;

- faza druga (1992-2004) - utrata poparcia prowadząca niemal do zniknięcia partii ze sceny politycznej;

- faza trzecia (2004-2007) - odrodzenie się Partii Zielonych i jej powrót do parlamentu.

Wskazane przez autorów fazy można również przenieść na ewolucję pozycji partii ekologicznych na scenach politycznych części omawianych państw Europy Środkowo-Wschodniej w porównywalnym okresie. Wydaje się, że do trzech faz wskazanych przez Sikka i Andersena można dodać czwarta, która charakteryzuje się znaczną utratą poparcia dla partii ekologicznych. Powoduje to usadowienie tych ugrupowań poza parlamentem, co jest wynikiem krytycznej oceny elektoratu co do niespełnionych obietnic wyborczych. Obecne miejsce ugrupowań ekologicz-

5 Podział systemów partyjnych omawianych państw na trzy grupy (państwa Grupy Wyszehradzkiej, państwa bałtyckie i bałkańskie) jest wyłącznie funkcjonalny i zastosowany w celu usystematyzowania materiału.

${ }^{6}$ Stan faktyczny w niniejszym artykule ustalony na 12.03.2011 r. uaktualniony o przebieg wyborów parlamentarnych na Słowenii, Słowacji i w Łotwie, które odbyły się w latach 2011-2012.

A. Sikk, R. Holmgaard Andersen, Without a Tinge of Red: The Fall and Rise of Estonian Greens, http://eprints.ucl.ac.uk/18585/1/18585.pdf, s. 8, dostęp 12.03.2011 r. 
nych w omawianych państwach po ostatnich wyborach parlamentarnych zostało przedstawione $\mathrm{w}$ tabeli 1 .

Tabela 1

Liczba mandatów do niższej izby parlamentu uzyskanych przez partie ekologiczne w państwach Europy Środkowo-Wchodniej po ostatnich wyborach (2008-2011) (stan na 4.10.2012 r.)

\begin{tabular}{|c|c|c|c|}
\hline & Nazwa ugrupowania politycznego & $\begin{array}{c}\text { Data ostatnich } \\
\text { wyborów } \\
\text { parlamentar- } \\
\text { nych }\end{array}$ & $\begin{array}{l}\text { Liczba man- } \\
\text { datów do } \\
\text { parlamentu } \\
\text { po ostatnich } \\
\text { wyborach }\end{array}$ \\
\hline Albania & $\begin{array}{l}\text { - Enwironmentalistyczna Partia Agrarna (Partia } \\
\text { Agrare Ambientaliste) } \\
\text { - Albańska Partia Zielonych (Partia e Gjelbër } \\
\text { e Shqipërisë) }\end{array}$ & $2009 \mathrm{r}$. & 0 mandatów \\
\hline Rumunia & \begin{tabular}{|l} 
- Rumuńska Partia Ekologiczna (Partidul Eco- \\
logist Român) \\
- Partia Zielonych (Partidul Verde) \\
- Rumuński Ruch Ekologiczny (Miscarea Eco- \\
logista din Romania)
\end{tabular} & $2008 \mathrm{r}$. & $\begin{array}{l}0 \text { mandatów } \\
0 \text { mandatów } \\
0 \text { mandatów }\end{array}$ \\
\hline Bułgaria & $\begin{array}{l}\text { - Klub Polityczny „Ekogłasnost” } \\
\text { (Политически клуб „Екогласност”) } \\
\text { - Zieloni (ПП Зелените) }\end{array}$ & 2009 r. & 0 mandatów \\
\hline Macedonia & \begin{tabular}{|l} 
- Partia Zielonych (Партија на Зелените) \\
- Partia Zielonych Macedonii (Зелена Партија \\
на Македонија)
\end{tabular} & $2011 \mathrm{r}$. & 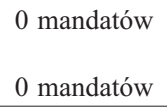 \\
\hline Słowenia & $\begin{array}{l}\text { - Partia Młodych - Europejscy Zieloni (Stranka } \\
\text { Mladih - Zeleni Evrope) } \\
\text { - Zieloni Słowenii (Zeleni Slovenije) }\end{array}$ & $2011 \mathrm{r}$. & $\begin{array}{l}0 \text { mandatów } \\
0 \text { mandatów }\end{array}$ \\
\hline Litwa & $\begin{array}{l}\text { - Litewska Partia Zielonych (Lietuvos zalioji } \\
\text { partija) }\end{array}$ & $2008 \mathrm{r}$. & 0 mandatów \\
\hline Lotwa & $\begin{array}{l}\text { - Lotewska Partia Zielonych (Latvijas Zaḷā Par- } \\
\text { tija) }\end{array}$ & $2011 \mathrm{r}$. & 4 mandaty \\
\hline Estonia & - Estońscy Zieloni (Erakond Eestimaa Rohelised) & $2011 \mathrm{r}$. & 0 mandatów \\
\hline Polska & $\begin{array}{l}\text { - Zieloni } 2004 \\
\text { - Partia Zielonych } \\
\text { - Partia Zielonych Rzeczypospolitej Polskiej }\end{array}$ & $2011 \mathrm{r}$. & $\begin{array}{l}0 \text { mandatów } \\
0 \text { mandatów } \\
0 \text { mandatów }\end{array}$ \\
\hline $\begin{array}{l}\text { Republika } \\
\text { Czeska }\end{array}$ & - Partia Zielonych (Strana Zelených) & $2010 \mathrm{r}$. & 0 mandatów \\
\hline Słowacja & - Partia Zielonych (Strana zelených) & $2012 \mathrm{r}$. & 0 mandatów \\
\hline Węgry & - Polityka Może Być Inna (Lehet Más a Politika) & $2010 \mathrm{r}$. & $\begin{array}{l}16 \text { mandatów } \\
\text { (obecnie 15) }\end{array}$ \\
\hline
\end{tabular}

Źródło: Opracowanie własne. 
Początek rosnącej pozycji partii ekologicznych w Europie Zachodniej przyniósł przełom lat 70. i 80. ubiegłego stulecia, jako rezultat instytucjonalizacji powstających wówczas ruchów ekologicznych. Część z tych ruchów, z powodu charakteru swoich postulatów, wysuwała wobec rządzących żądania radykalnych zmian w zakresie m.in. stworzenia bardziej restrykcyjnych regulacji prawnych w celu znaczącej poprawy stanu środowiska naturalnego. W Europie Środkowo-Wschodniej w tym samym czasie władze nie pozwalały na powstawanie niezależnych ruchów społeczno-politycznych, o partiach politycznych nie wspominając. W Polsce po 1989 roku istniał problem braku ruchu masowego poparcia dla ekologii, jak było to na Zachodzie (pokolenie '68). Katarzyna Dulko wskazuje również na swoisty stereotyp ,apolityczności” ekologii, który przejawiał się w tym, że sami ekolodzy nie chcieli być utożsamiani z konkretnymi podziałami „prawica-lewica”, a szansa powstała dopiero wówczas, kiedy doszło do wykształcenia się w polskim społeczeństwie nowej klasy średniej, które wiązane jest powszechnie z poparciem dla haseł głoszonych przez ugrupowania ekologiczne ${ }^{8}$.

\section{Partie ekologiczne w państwach bałtyckich}

W systemach partyjnych państw bałtyckich można zaobserwować tendencję pojawiania się partii ekologicznych na początku okresu transformacji i utratę poparcia dla nich w kolejnych wyborach parlamentarnych. Przykładem może być chociażby Litewska Partia Zielonych, która w wyborach w 1990 roku uzyskała poparcie 3,0\% ważnie oddanych głosów, co pozwoliło jej na obsadzenie 4 miejsc w parlamencie 9 . W następnych wyborach (1992) partia uzyskała $0,7 \%$, a kolejne lata przyniosły dalszą marginalizację ugrupowania ${ }^{10}$, z jej faktycznym wyeliminowaniem z litewskiej sceny politycznej ${ }^{11}$.

8 K. Dulko, Dyskurs ekologiczny $w$ praktyce wybranych zielonych partii politycznych, http://www.rybb.konin.lm.pl/pracamag.pdf, s. 53-54.

9 Wyniki wyborów parlamentarnych w całym artykule, o ile nie wskazano inaczej, podane za: University of Essex, Political Transformation and the Electoral Process in Post-Communist Europe, http://www.essex.ac.uk/elections/.

10 Działacz ekologiczny, Andrejus Gaidamavicius, słusznie zauważył, że ruchy ekologiczne na Litwie mają znikomą szansę na zyskanie poparcia, pomimo kilkukrotnych prób zakładania tego typu ugrupowań: „Obecnie na Litwie działają nawet dwie partie zielonych [...]. Potencjał ich jest bardzo nieduży, dlatego od wielu lat 
Rozwój partii ekologicznych w Estonii w ciagu całego procesu transformacji ustrojowej przebiegał w sposób bardzo zróżnicowany. Estońscy Zieloni (Eesti Rohelised) to partia powstała w 1991 roku w oparciu o połączenie, założonej w 1989 roku, Estońskiej Partii Zielonych (Eesti Roheline Partei) i, powstałej rok później, Partii Zielonych (Eesti Roheline Erakond). W 1994 roku, w pierwszych wolnych wyborach do estońskiego Zgromadzenia Państwowego, Zieloni, startujący jako koalicja kilku mniejszych partii i organizacji społeczno-politycznych, uzyskali 1 mandat $^{12}$. W następnych wyborach parlamentarnych ekolodzy weszli w koalicję wyborczą Czwarta Władza (Neljas Jõud (Kuningriiklased ja Rohelised)) z rojalistami, jednak pozwoliło to sojuszowi na zdobycie tylko 4377 głosów $(0,81 \%)$. Taki wynik spowodował utratę wszystkich mandatów posiadanych przez obie partie.

Wzrost poparcia dla ugrupowań ekologicznych w Estonii związany był z wyborami do Parlamentu Europejskiego, w których działacz ekologiczny, Marek Stranberg wystartował jako kandydat niezależny zdobywając 5372 głosy $^{13}$. Takie poparcie nie pozwoliło na uzyskanie mandatu do Parlamentu Europejskiego, ale pokazało, że ruch Zielonych posiada poparcie, które można przenieść na mandaty do parlamentu narodowe-

w żadnych wyborach nie uczestniczą. Druga partia zielonych była założona na czas wyborów do Parlamentu Europejskiego [...]. W kilku rejonach odbyły się zjazdy założycielskie, ale żaden z aktywistów Ruchu Zielonych nie był na nie zaproszony. Ich cel był jasny - na Litwie nie ma żadnej poważnej partii zielonych, więc warto spróbować dostać jakieś miejsce w Parlamencie Europejskim - niestety im się nie udało". Cyt. Las bez wilka - nie las. Rozmowa z Andrejusem Gaidamaviciusem, „Nasz Czas” 2007, nr 5 (699), http://www.pogon.lt/705/wywiad2.html, dostęp 11.03.2011 r.

1118 marca 2011 roku na stronie Europejskiej Partii Zielonych (European Green Party) została zamieszczona informacja o powstającej Litewskiej Partii Zielonych. W komunikacie stwierdzono, że Litwa jest ostatnim państwem członkowskim UE, które nie posiadało do tej pory aktywnego politycznego ugrupowania ekologicznego. EGP News: Foundation Green Party in Lithuania, http://europeangreens.eu/menu/ news/news-single/?tx_ttnews[tt_news] $=2337 \&$ tx_ttnews[backPid] $=1 \&$ cHash=eccba0563d\#, dostęp 24.03.2011 r.

12 Pomimo poparcia 2,62\% i nie przekroczenia pięcioprocentowego progu wyborczego, poparcie dla Reina Järlika ( $9 \%$ głosów w okręgu) spowodowało uzyskanie jednego mandatu, Riigikogu valimine 20. September 1992, http://www.vvk.ee/varasemad/? $\mathrm{v}=\mathrm{r} 92$, dostęp 12.03.2011 r.

${ }_{13}$ Elections to the European Parliament June 13, 2004, Distribution of mandates Mandates distributed on the basis of comparative figures, http://www.vvk.ee/varase-

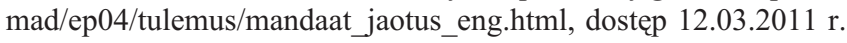


go. Wybory w 2007 roku potwierdziły to przypuszczenie - Estońscy Zieloni (Erakond Eestimaa Rohelised) otrzymali 6 mandatów (39 279 głosów - 7,14\%) i znaleźli się w opozycji do rządu Andrusa Ansipa.

W ostatnich wyborach parlamentarnych (2011) Zieloni otrzymali 21824 głosy (3,8\%), co pozostawiło partię poza Zgromadzeniem Państwowym. Należy zauważyć, że w porównaniu do poprzedniej elekcji, Zieloni stracili zaufanie niemal połowy swoich wyborców. Interesująca wydaje się być przyszłość tego ugrupowania. Gdy wydawało się już, że znaczący wzrost poparcia w 2007 roku zaowocuje jego dalszym wzrostem w kolejnych latach, wybory z 2011 roku pokazały, że idea enwironmentalizmu, głoszona przez omawiane ugrupowanie, została odrzucona.

Sytuacja łotewskiego ruchu ekologicznego pokazuje, że konsekwentnie prowadzona polityka wchodzenia w sojusze wyborcze z silniejszymi partiami może być remedium na swoistą „niewybieralność” ugrupowań ekologicznych. W pierwszych po 1989 roku wyborach parlamentarnych (do Rady Najwyższej Republiki Łotewskiej), Łotewska Partia Zielonych otrzymała 6 mandatów. W kolejnych wyborach, w 1993 roku, Zieloni otrzymali tylko $1,19 \%$ głosów ${ }^{14}$. Dostrzegając małe szanse dostania się do parlamentu, politycy tego ugrupowania doszli do wniosku, że muszą szukać porozumienia $\mathrm{z}$ większymi partiami i wchodzić w różnego rodzaju sojusze przedwyborcze. Pierwszym, który pozwolił na uzyskanie mandatów, był alians z Łotewską Narodową Partią Konserwatywną (Latvijas Nacionāli konservatīvā partija), dzięki któremu po wyborach z 1995 roku do parlamentu dostało się 8 deputowanych, a Indulis Emsis został ministrem środowiska.

W wyborach do łotewskiego Sejmu w 1998 roku, Łotewska Partia Zielonych wystartowała w sojuszu z Partią Pracy (Darba partijas) i Unią Chrześcijańsko-Demokratyczną (Kristīgi demokrātiskās savienības). Poparcie 22018 głosów (2,29\%) nie pozwoliło na uzyskanie mandatów w łotewskim parlamencie. Kolejne koalicje wyborcze ekolodzy zawierali już tylko z jedną partią - Centrową Partią Łotewską Związek Rolników (Centriskā partija Latvijas Zemnieku savienība). Koalicja wyborcza Związek Zielonych i Rolników (Zaļo un Zemnieku Savienība) w wyborach w 2002 roku uzyskała poparcie 9,4\% głosów, co pozwoliło na obsadzenie aż 12 mandatów w łotewskim Sejmie ${ }^{15}$. Lider Nowej Ery

14 5th Saeima elections, http://web.cvk.lv/pub/public/28763.html, dostęp 13.03.2011 r.

157 miejsc z 12 dla całej koalicji obsadzili ekolodzy, a w trakcie kadencji do ugrupowania przystąpiło jeszcze dwóch posłów. 
(Einars Repše), ugrupowania, które wygrało wybory parlamentarne w 2002 roku, podpisał z ZZS umowę koalicyjną. Umowa koalicji czterech partii umożliwiła powołanie rządu Einarsa Repše, w którym część resortów zostało obsadzone przez działaczy koalicji ZZS ${ }^{16}$.

Niewątpliwym sukcesem Łotewskiej Partii Zielonych było zasiadanie Indulisa Emsisa, wieloletniego lidera tego ugrupowania na stanowisku premiera Łotwy. Objęcie tego urzędu w marcu 2004 roku jest o tyle istotne, że Emsis był pierwszym politykiem pochodzącym z partii ekologicznej, który zasiadał na tak ważnym stanowisku państwowym. Choć polityk ten sprawował swoją funkcję jedynie przez 10 miesięcy ${ }^{17}$, to trzeba podkreślić, że jest to ważne wydarzenie w historii ruchu ekologicznego i partii enwironmentalistycznych.

W kolejnych wyborach (2006) poparcie dla koalicji ZZS wzrosło, dzięki czemu w Sejmie IX kadencji zasiadało aż 18 deputowanych (z czego 4 mandaty przypadły ekologom). Koalicja ZZS dołączyła do sojuszu z Partią Ludową (Tautas partija), koalicji ugrupowań Dla Ojczyzny i Wolności - Łotewski Narodowy Ruch Niepodległości (Tēvzemei un Brīvībai / Latvijas Nacionālās Neatkarības Kustība) i Pierwszej Partii Łotwy (Latvijas Pirmā Partija), dzięki czemu można było powołać rząd z premierem Aigarsem Kalvīisem na czele.

Wybory parlamentarne w 2010 roku pozwoliły na wzrost liczby mandatów w łotewskim parlamencie (wzrost z 18 do 22 miejsc w Sejmie), a w piętnastoosobowym rządzie Valdisa Dombrovskisa Związek Zielonych i Rolników posiadał 6 tek ministerialnych ${ }^{18}$. Nie podlega wątpliwości, że przyszła pozycja partii ekologicznej na łotewskiej scenie politycznej jest w dużej mierze uzależniona od jej dalszej współpracy ze współkoalicjantem - Związkiem Rolników. Wybory przedterminowe w 2011 roku nie zmieniły liczby miejsc przeznaczonych dla ekologów,

16 Ministerstwo środowiska objął Raimonds Vējonis (w 2003 roku otrzymał dodatkowo nadzór nad wykonywaniem kwestii rozwoju regionalnego), Mārtiņš Roze został ministrem rolnictwa, a tekę ministra zabezpieczenia społecznego objęła Dagnija Staķe.

17 Gabinet Emsisa nie otrzymał wotum zaufania. Na stanowisku premiera zastappił go Aigars Kalvītis.

18 Resortami tymi są: Ministerstwo Zdrowia, Ministerstwo Rolnictwa, Ministerstwo Środowiska i Rozwoju Regionalnego, Ministerstwo Transportu, Ministerstwo Zabezpieczenia Społecznego oraz Ministerstwo Edukacji i Nauki. Pełny skład rządu na stronie internetowej łotewskiego rządu: Composition of the Cabinet of Ministers of Valdis Dombrovskis, http://www.mk.gov.lv/en/mk/sastavs/, dostęp 25.03.2011 r. 
pomimo znacznego spadku liczby mandatów dla całej koalicji wyborczej $^{19}$, chociaż warto wskazać, że koalicja Związku Zielonych i Rolników po 17 września 2011 roku znalazła się w opozycji do rządu Valdisa Dombrovskisa, tracąc tym samym teki ministerialne.

\section{Miejsce partii ekologicznych $w$ bałkańskich systemach partyjnych (Albania, Bułgaria, Macedonia, Rumunia, Słowenia)}

Enwironmentalistyczna Partia Agrarna (Partia Agrare Ambientaliste) powstała w 1991 roku pod nazwą Agrarna Partia Albanii (Partia Agrare e Shqipërisë $)^{20}$. W programie partia odwołuje się do haseł agrarnych, ekologicznych, jak i reformistycznych. W pierwszych trzech elekcjach parlamentarnych po 1989 roku $(1991,1992,1996)$ agraryści nie uzyskali ani jednego mandatu, a poparcie dla partii nie przekraczało $0,6 \%$ głosów. W wyborach w 1997 roku ugrupowaniu udało się doprowadzić do zdobycia jednego mandatu, a cztery lata później poprawić swój wynik i wprowadzić do parlamentu trzech deputowanych. Przedostatnie wybory (2005) przyniosły temu ugrupowaniu największą liczbę mandatów od 1989 roku - 6, dzięki poparciu 6,6\% wyborców. Pomimo zasiadania w parlamencie łącznie tylko kilku deputowanych z PAA, agraryści posiadali swojego przedstawiciela w albańskim rządzie, którym był lider ugrupowania, Lufter Xhuveli (minister rolnictwa od 1998 roku i minister środowiska od 2002 roku). Wybory z 2009 roku wskazały na prawdopodobną marginalizację tej partii politycznej w przyszłości. Agraryści otrzymali poparcie tylko $0,9 \%$. Nowe prawo wyborcze ograniczało liczbę mniejszych ugrupowań w parlamencie, czego skutkiem było znalezienie się ugrupowania poza Zgromadzeniem Albanii ${ }^{21}$.

Ruch ekologiczny w Bułgarii funkcjonował na scenie politycznej nieco wcześniej niż w Albanii. Pierwszą zarejestrowaną partią ekologiczną była Partia Zielonych w Bułgarii (Зелена партия в България) ${ }^{22}$.

19 Związek Zielonych i Rolników ma obecnie 13 mandatów, w ramach których 4 są przydzielone ekologom.

20 O zmianie nazwy na obecną postanowiono w 2003 roku.

21 Nie można nie wspomnieć o funkcjonującej na scenie politycznej Albańskiej Partii Zielonych (Partia e Gjelbër) startującej w ostatnich wyborach parlamentarnych z list Socjalistycznego Ruchu Integracji (Lëvizja Socialiste për Integrim), które jednak do parlamentu nie wprowadziło ani jednego deputowanego.

22 Obecna nazwa partii to Partia Zielonych (Зелена партия). 
W 1990 roku powstał Klub Polityczny „Ekogłasnost” (dalej jako: KP „Ekogłasnost”) ${ }^{23}$. Ugrupowanie to powstało w oparciu o strukturę organizacyjną Niezależnego Stowarzyszenia „Ekogłasnost” i Komitetu na rzecz Ocalenia Miasta Ruse. W pierwszych wolnych i demokratycznych wyborach parlamentarnych, które odbyły się w 1990 roku, KP „Ekogłasnost” zdobył 17 mandatów, startując w koalicji Związku Sił Demokratycznych (Съюз на демократичните сили). Po konflikcie wewnątrz partii doszło do jej podziału, czego efektem był start partii w kolejnych wyborach w nowej koalicji (ZSD - Centrum) już z innymi ugrupowaniami $^{24}$. Koalicja ta nie przekroczyła jednak progu wyborczego i nie brała udziału w podziale mandatów.

Tabela 2

Liczba mandatów do parlamentu bułgarskiego po wyborach parlamentarnych w okresie 1990-2009

\begin{tabular}{|l|l|l||}
\hline $\begin{array}{c}\text { Rok } \\
\text { wyborów }\end{array}$ & $\begin{array}{c}\text { Liczba } \\
\text { mandatów do } \\
\text { parlamentu }\end{array}$ & \multicolumn{1}{|c||}{ Uwagi } \\
\hline 1990 & 17 mandatów & mandaty zdobyte w ramach ZSD \\
\hline 1991 & 0 mandatów & $\begin{array}{l}\text { koalicja ZSD-Centrum (w ramach, której startował Ekogłas- } \\
\text { nost) nie przekroczyła progu wyborczego }\end{array}$ \\
\hline 1994 & 7 mandatów & $\begin{array}{l}\text { mandaty zdobyte w ramach koalicji z Bułgarską Partią Socjali- } \\
\text { styczną i Bułgarskim Ludowym Związkiem Chłopskim - Blok } \\
\text { Narodowy. }\end{array}$ \\
\hline 1997 & brak danych & $\begin{array}{l}\text { Demokratyczna Lewica (koalicja Bułgarskiej Partii Socjali- } \\
\text { stycznej i Klubu Politycznego „Ekogłasnost”) otrzymała popar- } \\
\text { cie pozwalające obją́ 58 miejsc w parlamencie }\end{array}$ \\
\hline 2001 & 0 mandatów & $\begin{array}{l}\text { koalicja Zwiazzek Narodowy Ojczyzna i Lewica (sojusz Partii } \\
\text { Zielonych i Klubu Politycznego „Ekogłasnost”) }\end{array}$ \\
\hline 2005 & 0 mandatów & $\begin{array}{l}\text { KP „Ekogłasnost” nie został zarejestrowany przez Centralną } \\
\text { Komisję Wyborczą }\end{array}$ \\
\hline 2009 & 0 mandatów & \\
\hline \hline
\end{tabular}

Źródło: Opracowanie własne na podstawie: M. Popescu, M. Hannavy, Bulgaria-election, Project on Political Transformation and the Electoral Process in Post-Communist Europe, http://www2.essex.ac.uk/elect/database/indexElections.asp? country=BULGARIA\&election=bg2001, dostęp $11.03 .2011 \mathrm{r}$.

23 Nie należy przy tym zapominać o jeszcze jednej organizacji ekologicznej. W 1991 roku powstał Narodowy Ruch „Ekogłasnost”, zarejestrowany jako partia polityczna.

24 Były nimi m.in.: Bułgarska Partia Socjaldemokratyczna i Partia Demokratyczna - Płowdiw. 
Dwie kolejne elekcje to okres ścisłej współpracy z Bułgarską Partią Socjalistyczną (Българска социалистическа партия). Porozumienie wyborcze obu partii okazało się sukcesem: w wyborach z 1994 roku koalicja zwyciężyła, co dało Klubowi Politycznemu „Ekogłasnost” 7 mandatów i tekę ministra ${ }^{25}$. Po kryzysie politycznym na początku 1997 roku doszło do wyborów parlamentarnych, w których po raz kolejny KP „Ekogłasnost” wystartował z socjalistami pod szyldem koalicji Demokratyczna Lewica (Демократична левица). Poparcie dla koalicji prawie miliona głosów (939 308) umożliwiło uzyskanie 58 mandatów, co znacznie osłabiło pozycję lewicy i funkcjonującego w jej ramach KP „Ekogłasnost”.

Rok 2001 związany jest z początkiem procesu marginalizacji omawianej partii ekologicznej. W wyniku nieporozumień między liderami obu partii tworzących koalicję doszło do zerwania współpracy między socjalistami a KP „Ekogłasnost”. W tej sytuacji ekolodzy zostali zmuszeni do porozumienia się z innym ugrupowaniem ekologicznym - Partią Zielonych, by utworzyć alians wyborczy przed zbliżającymi się wyborami. Koalicja wyborcza Związek Narodowy Ojczyzna i Lewica (Национален съюз Отечество и Левица) zdobył bardzo niskie poparcie (21 851 głosów, 0,48\%) ${ }^{26}$, co wykluczyło ekologów z podziału mandatów. Zmarginalizowany KP „Ekogłasnost” został jeszcze bardziej osłabiony w wyniku decyzji Centralnej Komisji Wyborczej ${ }^{27}$, która odmówiła rejestracji list wyborczych tego ugrupowania. W 2005 roku partia podjęła współpracę z lewicową Koalicją dla Bułgarii (Коалиция за България). Obecnie rola KP „Ekogłasnost” w systemie partyjnym jest niezauważalna, a przyszłość tej partii stoi pod dużym znakiem zapytania.

25 Ministrem środowiska w rządzie Żana Widenowa był Georgi Dimitrow Georgijew.

26 M. Popescu, M. Hannavy, Bulgaria-election 2001, Project on Political Transformation and the Electoral Process in Post-Communist Europe, http://www2.essex.ac.uk/elect/database/indexElections.asp? country=BULGARIA\&election=bg2001, dostęp 11.03.2011 r.

27 Sprawa nr 4670/2005 w sprawie odwołania Klubu Politycznego „Ekogłasnost” od decyzji nt 90/2005 w sprawie Centralnej Komisji Wyborczej, która odmówiła rejestracji Klubu Politycznego „Ekogłasnost” w wyborach do 40. Zgromadzenia Narodowego (По адм. дело № 4670/2005 г. - Отхвърля жалбата на Политически клуб „Екогласност” срещу Решение № 90/2005 г. на ЦИК, с което е отказана регистрация на Политически клуб „Екогласност” за участие в изборите за 40-то HC.), http://www.sac.government.bg/home.nsf/0/4E1CA913AD35FAB5C225700 5004927A4, dostęp 11.03.2011 r. 
Nie należy zapominać o istniejących w Bułgarii innych ugrupowaniach ekologicznych. Jednym z nich jest powstała w 2008 roku nowa partia ekologiczna - Zieloni (Зелените). W pierwszych, po powstaniu, wyborach parlamentarnych uzyskała ona bardzo niskie poparcie $(0,52 \%)$ i nie zdobyła żadnego mandatu ${ }^{28}$.

We wrześniu 2009 roku trzy największe bułgarskie partie ekologiczne podpisały porozumienie. Były to: Klub Polityczny „Ekogłasnost” (Политически клуб „Екогласност”), Partia Zielonych („Партия на зелените”) i Partia Zielonych - Bułgarska Zieleń („Зелена партия - Български зелени"). Sojusz tych ugrupowań miał na celu wzmocnienie politycznego ruchu ekologicznego w Bułgarii przed kolejnymi wyborami parlamentarnymi ${ }^{29}$.

Wydaje się, że wzmocnienie pozycji partii ekologicznych na bułgarskiej scenie politycznej jest możliwe wyłącznie poprzez zjednoczenie się kilku ugrupowań o podobnym programie politycznym. Alians ugrupowań z 2009 roku może doprowadzić do powstania silnej koalicji wyborczej zdolnej do uzyskania kilku mandatów do parlamentu. Prawdziwym sprawdzianem poparcia dla partii ekologicznych w Bułgarii będą najbliższe wybory parlamentarne, które odbędą się najprawdopodobniej w 2013 roku.

W Macedonii ruch ekologiczny jest bardzo słaby, pomimo istnienia dwóch partii enwiromentalistycznych: Partii Zielonych (Партија на зелените) oraz Macedońskiej Partii Zielonych (Зелена партија на Македонија). Jednak ani jedna, ani druga partia nie zdobyła mandatu w którymkolwiek z wyborów parlamentarnych po 1989 roku, pomimo startowania w ostatnich latach w blokach wyborczych z większymi ugrupowaniami, które mandaty zdobywają.

Rumuńska Partia Ekologiczna (Partidul Ecologist Român - PER) w pierwszych po 1989 roku wyborach parlamentarnych (1990) odniosła swój triumf wyborczy zdobywając aż 8 mandatów do Izby Deputowanych. W dwóch kolejnych wyborach (w 1992 i 1996 roku) ugrupowanie przystapiło do koalicji wyborczej Rumuńskiej Konwencji Demokratycznej (Convenția Democrată Română). W skład koalicji wchodziło 6 partii politycznych (w tym dwa ugrupowania enwironmentalistyczne: Rumuń-

28 Парламентарни избори 2009, http://www.sredec.sofia.zelenite.bg/index.php?option $=$ com_content $\&$ view $=$ article $\&$ id $=94 \&$ Itemid $=68 \&$ lang $=B G /$, dostęp $11.03 .2011 \mathrm{r}$.

29 Марица вест, Българските зелени пред обединение, http://www.maritsa.com/ show.php?id=12510, dostęp 11.03.2011 r. 
ska Federacja Ekologiczna (Federația Ecologistă din România) i Rumuńska Partia Ekologiczna (Partidul Ecologist Român). Dzięki temu porozumieniu koalicja otrzymała w 1992 roku 82 mandaty parlamentarne, a 4 lata później - 122. W kolejnych wyborach ekolodzy wystapili już jako osobny komitet wyborczy, czego skutkiem był ich bardzo niski wynik wyborczy $-0,8 \%$ głosów, co uniemożliwiło dostanie się tej partii do Izby Deputowanych.

Drugie ugrupowanie ekologiczne, Rumuński Ruch Ekologiczny (Miscarea Ecologista din Romania - MER), uzyskało w 1990 roku 4 mandaty więcej od Rumuńskiej Partii Ekologicznej. Rok później, Marcian Bleahu, jako ekspert tego ugrupowania, został mianowany ministrem ochrony środowiska, jednak swój urząd sprawował niewiele ponad rok $^{30}$. MER w wyborach w 1992 roku stracił wszystkie mandaty, dlatego w kolejnej elekcji wystartował w koalicji wyborczej, jednak nie zapewniło to temu ugrupowaniu uzyskania miejsc w niższej izbie parlamentu.

Partia Zielonych Ekologów (Partidul Verde Ecologist) powstała w 2005 roku jako sojusz dwóch ugrupowań enwiromentalistycznych: Partii Zielonych (Partidul Verde) i Rumuńskiej Partii Ekologicznej (Partidul Ecologist Român). Koalicja do tej pory brała udział tylko w jednych wyborach parlamentarnych (2008) i z liczbą głosów 18279 (0,26\%) znalazła się poza parlamentem ${ }^{31}$.

Już w pierwszych wyborach parlamentarnych po 1989 roku $^{32}$, Zieloni Słowenii (Zeleni Slovenije) uzyskali poparcie 8,8\% głosów obywateli, które pozwoliło na obsadzenie 8 z 80 miejsc w słoweńskim parlamencie. W kolejnych wyborach do parlamentu (1992 rok), Zieloni uzyskali 5 mandatów ${ }^{33}$. Kolejne elekcje pokazywały, że utrata trzech mandatów w 1992 roku w stosunku do wyborów z 1990 roku, jest zwiastunem tendencji malejącego poparcia dla słoweńskiej partii ekologicznej:

- wybory w 1996 roku - 18853 głosy i poparcie rzędu 1,76\% ważnie oddanych głosów ${ }^{34}$;

30 Agentiei Nationale de Presa, Guvernele Romaniei - Guvernul Theodor Stolojan, http://documentare.rompres.ro/guverne.php?i=9, dostęp 29.11.2011 r.

31 Romania Biroul Electoral Central Alegeri Parlamentare - 30 Noiembrie 2008, http://www.becparlamentare2008.ro/rezul/part_tara_100.pdf, dostęp 1.04.2011 r., s. 1.

32 Odbyły się one 9 kwietnia 1990 roku.

33 Composition of the National Assembly in the year 1992, http://volitve.gov.si/ dz1992/en/92urpa.htm, dostęp 12.03.2011 r.

34 Pojawiło się nowe ugrupowanie ekologiczne - Zielona Alternatywa Słowenii (Zelena alternativa Slovenije - Zelena alternativa), jednak uzyskało poparcie ponad 
- wybory w 2000 roku - w elekcji wzięły udział połączone siły ekologiczne pod szyldem Zjednoczonych Zielonych - Zieloni Słowenii i Zielona Alternatywa; efektem tego było poparcie rzędu 0,9\% głosów; - wybory w 2004 roku - Zieloni Słowenii uzyskali 0,7\% głosów.

Ekolodzy na słoweńskiej scenie politycznej byli częścią antykomunistycznej opozycji na przełomie lat 80. i 90. XX wieku, co zdecydowanie mogło być powodem tak dużego poparcia dla tego ruchu społeczno-politycznego w 1989 roku. Anna Reynolds powodu spadku poparcia dla omawianych ugrupowań upatruje w niedotrzymaniu obietnic przedwyborczych przez współrządzących państwem ekologów ${ }^{35}$.

W wyborach w 2004 roku pojawiła się nowa partia polityczna - Partia Młodych Słowenii (Stranka mladih Slovenije), która uzyskała poparcie rzędu 2,1\% głosów. Ugrupowanie to opowiadało się przede wszystkim za większym udziałem młodych w polityce i było swego rodzaju reakcją na zastaną sytuację polityczną w Słowenii, która miała wyrażać się rzekomym zabetonowaniem sceny politycznej. Młodzi zieloni za fundament swojej działalności postawili program oparty na enwironmentalizmie.

W Słowenii obecnie najbardziej popularnymi partiami ekologicznymi są Zieloni Słowenii (Zeleni Slovenije) i Partia Młodych Słowenii ${ }^{36}$. W wyborach parlamentarnych w 2008 roku Zieloni Słowenii otrzymali poparcie 5366 głosów (0,51\%), a Partia Młodych w koalicji ze Słoweńską Partią Ludową (Slovenska ljudska stranka) - 54809 głosów (5,21\%), co pozwoliło koalicji na obsadzenie 5 mandatów w słoweńskim parlamencie. Wszystkie mandaty koalicji zostały przyznane Słoweńskiej Partii Ludowej. W ostatnich wyborach parlamentarnych z 2011 roku Zieloni Słowenii otrzymali dokładnie 4 tysiące głosów, a Partia Młodych Słowenii ponad dwa razy więcej (9532 głosy). Duże trudności przysparza wskazanie możliwej ewolucji pozycji partii ekologicznych w Słowenii. $\mathrm{Z}$ jednej strony poparcie społeczeństwa słoweńskiego dla obu partii maleje, z drugiej jednak - Partia Młodych jako ruch polityczny prze-

trzykrotnie mniejsze (5602 głosów stanowiących 0,52\%) od Zielonych Słowenii. Composition of the National Assembly in the year 1996, http://volitve.gov.si/ dz1996/en/eurvs26.htm, dostęp 12.03.2011 r.

${ }^{35}$ Ekolodzy obiecywali przeprowadzenie referendum w sprawie energii jądrowej. A. Reynolds, Balance of Power and Greens in Government - experiences in Europe, Australian Political Exchange Individual Study Tour, http://greeninstitute.org.au/projects/files/2011/02/2011-03-07-Greens-in-balance.pdf, s. 5.

36 Obecna nazwa ugrupowania to Partia Młodych Europejscy Zieloni (Stranka Mladih - Zeleni Evrope). 
kształcony w partię polityczną może zyskać poparcie wśród młodszych generacji słoweńskiego społeczeństwa.

\section{Partie ekologiczne w państwach Grupy Wyszehradzkiej (Polska, Republika Czeska, Słowacja i Węgry)}

Polityczny ruch ekologiczny w Polsce nie został przez społeczeństwo polskie przyjęty z dużym entuzjazmem. Partie enwiromentalistyczne funkcjonujące obecnie w Polsce to: Zieloni 2004, Partia Zielonych oraz Partia Zielonych $\mathrm{RP}^{37}$. Należy jednak podkreślić, że ugrupowania te nie uczestniczą aktualnie w walce o mandaty do parlamentu, co karze wątpić w spełnianie podstawowej determinanty jaką grupa społeczna musi spełniać, by nosić status partii politycznej tj. walka o władzę ${ }^{38}$. Na marginesie należy podkreślić dość ciekawe zjawisko utożsamiania partii ekologicznych w Polsce wyłącznie z lewicą, co jest jednak osobną kwestią, wartą osobnego podjęcia tematu ${ }^{39}$.

Partie ekologiczne na czeskiej scenie politycznej przez Davida Šanca zostały określone jako podmioty o marginalnym znaczeniu. Czeska Partia Zielonych (Strana Zelených) powstała 9 grudnia 1989 roku. W pierwszych wolnych i demokratycznych wyborach ugrupowanie zdobyło $4,1 \%$ głosów, co nie pozwoliło na zdobycie mandatów do parlamentu ${ }^{40}$.

37 Państwowa Komisja Wyborcza, Wykaz partii politycznych, http://pkw.gov.pl/wykaz-partii-politycznych/wykaz-partii-politycznych.html, dostęp 31.09.2011 r.

${ }^{38} \mathrm{~W}$ ostatnich wyborach parlamentarnych żadna $\mathrm{z}$ trzech partii ekologicznych nie wystawiła swojego komitetu wyborczego. Por. Państwowa Komisja Wyborcza, Wybory 2011 do Sejmu i Senatu Rzeczypospolitej Polskiej, http://wybory2011.pkw. gov.pl/kom/pl/komitety.html, dostęp 31.09.2011 r.

39 Rzadko przywoływanym faktem jest w tym kontekście fakt dołączenia Polskiej Partii Ekologicznej Zieloni do powstającej w połowie 1996 roku centroprawicowej koalicji Akcji Wyborczej Solidarność. Por. A. Lewandowski, Akcja Wyborcza „, Solidarność” - prawica zjednoczona, prawica rozbita, Dialogi Polityczne 11/2009, Toruń 2009, s. 111-112.

40 Autor bierze pod uwagę tylko wybory do parlamentu czeskiego, pomijając w niniejszym opracowaniu wybory z 1990 i 1992 roku do parlamentu federalnego. W 1990 roku w wyborach do Zgromadzenia Federalnego Partia Zielonych otrzymała: 3,44\% i 3,1\% (w obu izbach parlamentu federalnego) i tym samym nie uzyskała żadnego mandatu. Dwa lata później koalicja Związek Liberano-Socjalny (Liberálne sociální unie) zdobyła 12 mandatów. M. Popescu, M. Hannavy, Czech republic-election, Project on Political Transformation and the Electoral Process in 
W kolejnych wyborach jego kierownictwo postanowiło wejść w sojusz partii lewicowych - Związek Liberano-Socjalny (Liberálne sociální unie). Koalicja uzyskała 6,5\% głosów, co pozwoliło jej na obsadzenie 16 miejsc w parlamencie. Kolejne wybory nie pozwalały Zielonym dostać się do Izby Poselskiej (podobnie z resztą jak i do Senatu) ${ }^{41}$. Wybory z 2002 roku przyniosły Partii Zielonych znaczący wzrost poparcia w stosunku do elekcji z 1998 roku (z 67143 do 112929 głosów), co nie wystarczyło jednak by ugrupowanie partycypowało w podziale mandatów ${ }^{42}$. Po objęciu stanowiska przewodniczącego partii przez Martina Bursíka w 2005 roku ugrupowanie utraciło część swoich członków, którzy nie zgadzali się z pomysłem szefa partii, by Partia Zielonych startowała samodzielnie w najbliższych wyborach. Należy wskazać również, że ten wybór oznaczał znaczące złagodzenie linii programowej partii, ze względu na odejście radykalnych członków ${ }^{43}$. Rok później odbyły się wybory parlamentarne, w których Zieloni uzyskali poparcie 336487 głosów, dzięki czemu uzyskali 6 mandatów. Obywatelska Partia Demokratyczna (Občanská demokratická strana), Unia Chrześcijańskich Demokratów - Czechosłowacka Partia Ludowa (Křest'anská a demokratická unie Československá strana lidová) oraz Partia Zielonych podpisały umowę koalicyjną, która umożliwiła powstanie rządu na czele z Mirkiem Topolánkiem ${ }^{44}$. Wotum zaufania dla rządu zostało uchwalone w stosunku

Post-Communist Europe, http://www2.essex.ac.uk/elect/database/indexElections.asp? country $=\mathrm{CZECH}+$ REPUBLIC\&election $=\mathrm{cz} 92$ chamberPeople, dostę 11.03.2011 r.; M. Popescu, M. Hannavy, Czech republic-election, Project on Political Transformation and the Electoral Process in Post-Communist Europe, http://www2.essex.ac.uk/elect/database/indexElections.asp?country $=\mathrm{CZECH+REPUBLIC \& election}=$ cz92chamberNations, dostęp 11.03.2011 r.

41 Jedyny mandat senatorski Partia Zielonych wywalczyła w 2004 roku, kiedy to do Senatu został wybrany Jaromír Štětina.

42 Volby do Poslanecké sněmovny Parlamentu České republiky konané ve dnech 19-20.6.1998, http://www.volby.cz/pls/ps1998/u4, dostęp 11.03.2011 r.; Volby do Poslanecké sněmovny Parlamentu České republiky konané ve dnech 14-15.6.2002, $\mathrm{http}: / /$ www.volby.cz/pls/ps2002/ps2?xjazyk=CZ, dostęp 11.03.2011 r.

43 Zob. szerzej: D. Šanc, Czeski system partyjny a wybory w roku 2006 - problematyka piqtego podmiotu parlamentarnego, w: Czechy. Polska. Ukraina. Partie i systemy partyjne. Stan i perspektywy, red. K. Kowalczyk, Ł. Tomczak, Torun 2007, s. 205-207.

${ }^{44}$ Pomimo obsadzenia tylko 6 mandatów w dwustuosobowej Izbie Poselskiej, Zieloni otrzymali aż 4 teki ministerialne: ministrem środowiska został Martin Bursík (został też wicepremierem), ministrem spraw zagranicznych został bezpartyjny Karel Schwarzenberg, a Ministerstwo Edukacji, Młodzieży i Kultury Fizycznej objął 
100:97, co wskazywało na nie posiadanie przez rząd (współtworzony przez Partię Zielonych) stabilnej większości w parlamencie. W marcu 2009 roku parlament uchwalił gabinetowi wotum nieufności ${ }^{45}$.

W ostatnich wyborach parlamentarnych (2010), Partia Zielonych utraciła poparcie z 2006 roku, gdyż zdobyła 127831 głosów, co nie pozwoliło jej na wejście do parlamentu. Wydaje się, że ewolucja pozycji tego ugrupowania na scenie politycznej Czech pozwala na wskazanie marginalizacji jako kierunku rozwoju tej partii.

Podobnie jak w przypadku Czech, tak i na Słowacji geneza partii ekologicznych związana jest z rokiem 1989, kiedy to założono Partię Zielonych na Słowacji (Strana zelených na Slovensku). W pierwszych wyborach, w których ugrupowanie brało udział, uzyskało poparcie rzędu 3,49\% ważnie oddanych głosów (dokładnie 117871 głosów), co pozwoliło na obsadzenie 6 mandatów w Słowackiej Radzie Narodowej. Jednak kolejne wybory pokazały, że poparcie dla ugrupowań ekologicznych na Słowacji nie jest trwałe. Zarówno Partia Zielonych na Słowacji, jak i powstała później Partia Zielonych (Strana zelených) nie przekroczyły łącznie poprzedniego wyniku Partii Zielonych na Słowacji: pierwsza z partii zyskała poparcie $2,14 \%$ głosów, a druga $-1,08 \%{ }^{46}$, co nie pozwoliło na obsadzenie mandatów do parlamentu kolejnej kadencji.

Przed wyborami parlamentarnymi w 1994 roku Partia Zielonych na Słowacji podpisała umowę koalicyjną z trzema innymi partiami (Demokratyczna Partia Lewicy, Socjaldemokratyczna Partia Słowacji oraz Ruch Rolników Republiki Słowackiej) tworząc Wspólny Wybór (Spoločná vol'ba). W elekcji w 1994 roku sojusz ten uzyskał poparcie 10,41\%, co umożliwiło obsadzenie 18 miejsc w 150-osobowym słowackim parlamencie. W 1997 roku sojusz rozpadł się, a w kolejnych wyborach Zieloni podjęli współpracę z Unią Demokratyczną (Demokratická únia), Ruchem Chrześcijańsko-Demokratycznym (Krest’anskodemokratické hnutie),

Ondřej Liška. Ponadto ministrem bez teki (odpowiedzialnym za prawa człowieka i mniejszości narodowych) został bezpartyjny Michael Kocáb (później zastapiony przez Džamilę Stehlíkovą).

45 Jest to o tyle istotne, że za wotum nieufności, które wysunęła opozycja centrolewicowa, głosowało dwóch deputowanych z ramienia Partii Zielonych, która była wówczas współkoalicjantem. Czechy: Izba Poselska uchwaliła wotum nieufności dla rzadu, http://wiadomosci.gazeta.pl/Wiadomosci/1,80708,6421179,Czechy_Izba_Poselska_uchwalila_wotum_nieufnosci_dla.html, dostęp $11.03 .2011 \mathrm{r}$.

46 Partia Zielonych na Słowacji otrzymała 66010 głosów, a Partia Zielonych -33372 . 
Partią Demokratyczną (Demokratická strana) i Socjaldemokratyczną Partią Słowacji (Sociálnodemokratická strana Slovenska). Utworzona wówczas koalicja Słowacka Koalicja Demokratyczna (Slovenská demokratická koalícia), uzyskała 42 miejsca w Radzie Narodowej (z czego sami ekolodzy otrzymali 4 mandaty). W efekcie tych wyborów, po porozumieniu się SDK z Partią Demokratycznej Lewicy, Partią Węgierskiej Koalicji i Partią Porozumienia Obywatelskiego, Mikuláš Dzurinda został premierem.

W 2002 roku Partia Zielonych na Słowacji wystartowała samodzielnie uzyskując 28365 głosów $(0,98 \%)^{47}$. Na początku 2006 roku ugrupowanie zmieniło nazwę na Partia Zielonych (Strana zelených), a w wyborach, które odbyły się $\mathrm{w}$ tym samym roku ugrupowanie nie wzięło udziału. W ostatnich wyborach parlamentarnych (2010), Zieloni startowali z list Partii Demokratycznej Lewicy (Strana demokratickej l'avice - SDL). Poparcie dla tego aliansu było bardzo niskie i sięgnęło 2,41\% ważnie oddanych głosów, co spowodowało, że po raz kolejny ekolodzy znaleźli się poza parlamentem.

Wyniki wyborów parlamentarnych z 2010 roku wskazują jednoznacznie, że popularność partii ekologicznych w społeczeństwie słowackim jest bardzo niska. Dwa lata później w wyborach Zieloni otrzymali jedynie 7860 głosów. Najbardziej prawdopodobnym scenariuszem dla Zielonych na Słowacji, jest albo doprowadzenie do sojuszu z ugrupowaniem większym niż SDL albo jeszcze większa marginalizacja.

Na Węgrzech geneza i obecna pozycja partii ekologicznej Polityka Może Być Inna (Lehet Más a Politika - LMP) jest bardzo podobna jak słoweńskiej Partii Młodych. Podobnie jak partia słoweńska, tak i LMP powstało jako partia sprzeciwu. Węgierskie ugrupowanie powstało w 2009 roku w oparciu o ruch społeczny opowiadający się za walką z korupcją wśród polityków oraz promowaniem polityki zrównoważonego rozwoju. W wyborach w 2010 roku uzyskało poparcie 427313 głosów, co umożliwiło obsadzenie 16 spośród 386 miejsc w węgierskim parlamencie ${ }^{48}$. Aktualnie w wegierskim Zgromadzeniu Narodowym zasiada 15 posłów $\mathrm{LMP}^{49}$.

47 Number and share of valid votes for political parties, Elections 2002, http://app.statistics.sk/volby2002/webdata/engl/tab/tab3.htm, dostęp 13.03.2011 r.

48 National Election Office - 2010 Parliamentary Elections, http://www.valasztas.hu/en/parval2010/298/298_0_index.html, dostęp 26.03.2011 r.

49 Az ország háza, http://www.mkogy.hu/internet/plsql/ogy_angolkpv.frak_tab_a?p_vezer=m\&P_DATUM=2011.03.26.19:46:53\&p_pcs=14, dostęp 26.03.2011 r. 


\section{Podsumowanie}

Podsumowując, należy zauważyć, że największe poparcie, partie ekologiczne w państwach środkowoeuropejskich uzyskują w państwach bałtyckich, a także w trzech z czterech państw Grupy Wyszehradzkiej ${ }^{50}$ (na Słowacji i Węgrzech oraz w Republice Czeskiej). Tylko w kilku spośród tzw. państw bałkańskich ${ }^{51}$ partie ekologiczne zdobywają poparcie pozwalające im na otrzymanie $\mathrm{z}$ reguły kilku mandatów do parlamentu.

K. Dulko przedstawia kilka ciekawych wniosków na temat ugrupowań enwiromentalistycznych w Europie Środkowo-Wschodniej:

- partie zielone w omawianym regionie dochodziły do władzy tylko wtedy kiedy było to w interesie dominujących sił politycznych;

- uczestniczyły w szerokich opozycjach antykomunistycznych i jako ich element, odegrały pozytywną rolę w procesie transformacji;

- etykieta organizacji ekologicznych (zielonych) posłużyła pojedynczym karierom ich liderów;

- nie zaistniała szeroka zielona polityka w rozumieniu zachodnim, gdyż te partie były przede wszystkim ruchami ekologicznymi, które nie zajmują się kwestiami lewicowo-libertariańskimi czy quasi-pacyfistycznymi;

- wchodziły do gabinetów ze słabą pozycją (zarówno mniej wartościowe ministerstwa jak i tylko jako pojedyncze osoby) ${ }^{52}$.

Nie sposób nie zgodzić się z autorką co do pierwszych czterech konkluzji, jednak wątpliwości budzi ostatni wniosek. Przykładem zaprzecza-

50 Grupa Wyszehradzka jest nazwą spotkań głów państw czterech środkowoeuropejskich krajów postkomunistycznych (Republiki Czech, Republiki Węgier, Rzeczypospolitej Polskiej i Republiki Słowackiej). Na początku grupa nazywana była Trójkątem Wyszehradzkim, jednak w wyniku podziału Czechosłowacji na dwa państwa, nazwę zmieniono na Grupa Wyszehradzka. Współpraca miała się odbywać głównie na płaszczyźnie politycznej i gospodarczej. Zob. szerzej: Historia Grupy Wyszehradzkiej, The Visegrad Group: the Czech Republic, Hangary, Poland and Slovakia - Historia V4, http://visegradgroup.eu/main.php?folderID=1030, dostęp 14.03.2011 r.

51 Chociaż część z tzw. państw bałkańskich nie leży w całości na Półwyspie Bałkańskim, to posługiwanie się tym terminem w odniesieniu do państw Europy Południowej w niniejszym artykule zastosowane jest głównie w celach usystematyzowania materiału.

52 Por. K. Dulko, Dyskurs ekologiczny w praktyce wybranych zielonych partii politycznych, http://www.rybb.konin.lm.pl/pracamag.pdf, s. 53. 
jącym powyższej tezie może być chociażby kazus czeskiego gabinetu po ostatnich wyborach parlamentarnych, w którym, jak zostało to już wcześniej zauważone, Zieloni otrzymali aż cztery teki ministerialne, w tym tak ważne resorty jak: ministerstwo spraw zagranicznych czy ministerstwo środowiska połączone $\mathrm{z}$ funkcją wicepremiera.

Można wreszcie stwierdzić, że w przeciwieństwie do zachodnioeuropejskiego ruchu ekologicznego, Europa Środkowa i Wschodnia nie jest areną walki ugrupowań enwiromentalistycznych o władzę, ale o egzystencję którą może zapewnić dotacja z budżetu za przekroczenie określonego progu wyborczego. Można doszukiwać się szeregu przyczyn takiego zjawiska. Pierwszym, które wynika niemal wprost z analizy poziomu rozwoju gospodarczego społeczeństw Europy Zachodniej i Europy Wschodniej, jest niska świadomość społeczna obywateli i nierozerwalnie z tym związana potrzeba zapewnienia bezpieczeństwa materialnego, w pierwszym rzędzie, przed bezpieczeństwem ekologicznym ${ }^{53}$.

Państwa bałtyckie stanowią ciekawy obraz możliwości jakie moga spotkać ugrupowania ekologiczne w tej części Europy: pomimo początkowego sukcesu wyborczego, tracą później poparcie i permanentnie znajdują się poza sceną polityczną (Litwa); początkowo uzyskują poparcie, jednak na skutek różnych zawirowań politycznych tracą wszystkie mandaty, by później na nowo wrócić do parlamentu (Łotwa); oraz trzeci wariant - naprzemiennie pojawiają się i znikają ze sceny politycznej (Estonia). Wydaje się, że spośród trzech państw bałtyckich obecnie jedynie Łotwa wpisuje się w model Allana Sikka i Rune'a Holmgaarda Andersena. Na skutek utraty mandatów w 2011 roku, estońskie ugrupowania ekologiczne znalazły się poza parlamentem. Wydaje się, że należałoby zatem dopisać do koncepcji skandynawskich politologów kolejną fazę, która charakteryzowałaby się znaczącą marginalizacją partii ekologicznych. Czy taka marginalizacja jest skutkiem dużego niezadowolenia z niedostatecznego spełnienia obietnic przedwyborczych przez wybranych do parlamentu ekologów? Odpowiedź na to pytanie, podobnie jak i problem dalszej marginalizacji ugrupowań ekologicznych powinny być przedmiotem dalszych, pogłębionych badań.

53 Prof. A. Antoszewski wskazując na tę przyczynę wymienia jeszcze jedną. Jego zdaniem zieloni z Europy Środkowo-Wschodniej nie występowali w swych programach z nową kwestią (jak miało to miejsce na Zachodzie), ale powielali postulaty już sformułowane, co odebrało im - jak chce prof. Antoszewski - „cechę świeżości”. Por. A. Antoszewski, Partie i systemy partyjne..., op. cit., s. 194. 
W odniesieniu do państw bałkańskich model Allana Sikka i Rune’a Holmgaarda Andersena nie sprawdza się zarówno w przypadku Albanii (przy początkowym braku poparcia, ekolodzy w 1997 roku dostali się do parlamentu, by w 2009 znaleźć się poza nim) i Rumunii (przy początkowym sukcesie ekologów, od połowy lat 90. w parlamencie przedstawiciele ugrupowań ekologicznych nie zasiadają) nie wspominając o macedońskich ekologach, którzy pomimo wchodzenia w strategiczne alianse $\mathrm{z}$ większymi ugrupowaniami, nie są w stanie uzyskać mandatów. Zastanawiać może przypadek bułgarski, który przypomina sytuację partii ekologicznych w Estonii: po początkowym sukcesie wyborczym (17 deputowanych w 1990 r.), bułgarscy ekolodzy znaleźli się poza parlamentem, by w 1994 roku do niego powrócić z 7 mandatami. W każdych kolejnych wyborach enwiromentaliści nie uzyskiwali poparcia pozwalającego na zasiadanie w parlamencie.

W państwach Grupy Wyszehradzkiej partie ekologiczne odgrywają nieco większą rolę aniżeli w pozostałych dwóch grupach. Wyjątkiem jest tutaj Polska, której obywatele nie darzą ekologów większym zaufaniem. Kazus czeskiej sceny politycznej idealnie pokazuje, że z pozoru niewielka partia (jaką było ugrupowanie ekologiczne) może stać się kluczem do zawarcia porozumienia koalicyjnego i do stworzenia stabilnej większości umożliwiającej rządzenie. Z kolei przypadek węgierski wskazuje, że skupienie dwóch czynników: niezadowolenia społecznego spowodowanego korupcją na szczytach władzy oraz idei zrównoważonego rozwoju w oddolnym ruchu społecznym (przekształcającym się w ruch polityczny) może być sposobem na zdobycie przez ekologów parlamentarnych mandatów.

Do wniosków końcowych warto dopisać stwierdzenie, że obecnie w Europie Środkowo-Wschodniej partie ekologiczne skazane są na daleko idącą marginalizację, a jedynym remedium wydaje się być tylko i wyłącznie wchodzenie $\mathrm{w}$ alianse wyborcze $\mathrm{z}$ silniejszymi graczami na scenach politycznych ${ }^{54}$. Wskazany jest również, z jednej strony, udział w debacie publicznej na temat problemów współczesnego świata i kładzenie $\mathrm{w}$ nich nacisku na zagrożenia wynikające z korzystania $\mathrm{z}$ energii atomowej w państwach, których rządy takie rozwiązania przewidują, ale $\mathrm{z}$ drugiej strony - poszerzanie płaszczyzn dialogu ${ }^{55}$. Przyszłe

54 Choć i to nie musi zapewniać sukcesu wyborczego, co idealnie wydaje się ilustrować przypadek macedońskich ekologów.

55 Przykładem traktowania kwestii ochrony środowiska jako jedynie dodatkowego tematu w dyskursie politycznym są czescy Zieloni. Jak wskazuje D. Šanc, atutem 
miejsce ruchów i partii ekologicznych winno stać się przedmiotem dalszych badań.

\title{
Marginalization of green parties on the political stage of Central and East European states at the time of political transformation
}

\begin{abstract}
Summary
In the period 2008-2011, twelve parliamentary elections were held in eight Central and East European states. Their results demonstrated the decreasing importance of green parties on the political stage in this part of Europe. The author of this paper tries to translate the concept developed by Allan Sikk and Rune Holmgaard Andersen, concerning the evolution of Estonian green parties, to party systems in CEE states. The paper also discusses the evolution of the status of green parties and their probable placement in party systems following the nearest parliamentary elections.
\end{abstract}

ugrupowania jest fakt, że liberalne stanowisko jej przedstawicieli łączy się (a zarazem je ogranicza) z naciskiem na tradycyjny dla tych partii enwiromentalizm. Por. D. Šanc, Czeski system partyjny a wybory..., op. cit., s. 205-207. 